S.Kh. Oshurbekov, V.M. Kazakbaev, V.A. Prakht, V.A. Dmitrievskii, A.S. Paramonov

\title{
ANALYSIS OF ELECTRICITY CONSUMPTION OF INDUCTION MOTORS OF IE1 AND IE2 EFFICIENCY CLASSES IN A 11 kW PUMP INSTALLATION
}

Purpose. Comparative analysis of energy consumption indicators of electric motors of different energy efficiency classes in an electric drive of a centrifugal pump with power of $11 \mathrm{~kW}$ of a water supply system with throttle regulation. Methodology. In this paper a comparison of energy consumption of $11 \mathrm{~kW}$ pump units with induction motors of energy efficiency classes IE1 and IE2 is presented. The induction motors are powered directly from the mains. Both considered pump configurations have the same fluid flow rate characteristic of open pump systems. The amount of water consumed by the pump is adjusted by throttling. Results. The results on the daily and annual energy consumption of the two considered pump system configurations are obtained. It is shown that the pump unit using the IE2 class motor provides the annual energy savings of 9.65 thousand rubles and the life cycle energy savings of 158 thousand rubles compared to the IE1 class motor. The payback period of the IE2 class motor is calculated, which is 5 months if a new installation is commissioned and 2 years if the motor is replaced in an operating installation. Practical value. Nowadays the countries of the Eurasian Economic Union mainly use electric motors of the lowest energy efficiency class IE1, according to the IEC 60034-30 Standard (GOST IEC 60034-30-1-2016). However, according to the decision of the Commission of the Eurasian Economic Union, since the 1st of September, 2021 all general-purpose motors shall not be less efficient than the IE2 efficiency level. Therefore, the analysis of the economic effect of replacing IE1 class motors with IE2 class motors becomes relevant for the countries of the Eurasian Union. Pump drives are one of the most important consumers of electricity. Most of the pump drives are powered directly from the mains. References 25, tables 5, figures 4.

Keywords: centrifugal pump, energy consumption, energy efficiency, induction motor, payback period, throttle control.

На сьогоднішній день в краӥнах Свразійського економічного союзу в основному застосовуються електродвигуни низького класу енергоефективності IЕ1, відповідно до стандарту МЕК 60034-30 (ГОСТ МЕК 60034-30-1-2016). Однак, згідно з рішенням комісії Свразійського економічного союзу, з 1 вересня 2021 р значення коефіцієнта корисної дії двигунів не повинно бути менше значень, встановлених для класу енергетичної ефективності IЕ2. Тому для краӥн Свразійського союзу актуальним стає аналіз економічного ефекту від заміни двигунів класу IЕ1 на двигуни класу ІЕ2. У даній роботі представлений порівняльний аналіз показників енергоспоживання асинхронних електродвигунів класів енергоефективності IE1 і IE2 в електроприводі відцентрового насоса потужністю 11 кВт системи водопостачання 3 дросельним регулюванням. Асинхронні двигуни жсивляться безпосередньо від електричної мережі. Обидві насосні системи мають один і той жее графік витрати рідини, характерний для розімкнутих насосних систем. Кількість витрачається насосом води регулюсться за рахунок дроселювання. Отримано результати по добовому і річному енергоспоживанню двох розглянутих конфігурацій насосної системи. Показано що система, де застосовується асинхронний двигун класу енергоефективності IЕ2, забезпечує економію 118,6 євро за рік $і 2000$ євро за жситтевий цикл, в порівнянні з асинхронним двигуном класу IЕ1. Розрахований термін окупності двигуна класу IE2, який складає 5 місяців в разі введення в дію нової установки 2 роки, в разі заміни двигуна в працюючій установці. Бібл. 25 , табл. 5 , рис. 4.

Ключові слова: асинхронний двигун, відцентровий насос, дросельне регулювання, енергоефективність, енергоспоживання, термін окупності.

На сегодняиний день в странах Евразийского экономического союза в основном применяются электродвигатели низкого класса энергоэффективности IЕ1, согласно стандарту МЭК 60034-30 (ГОСТ МЭК 60034-30-1-2016). Однако, согласно решению комиссии Евразийского экономического союза, с 1 сентября 2021 2. значение коэффициента полезного действия двигателей не долюно быть меньше значений, установленных для класса энергетической эффективности IЕ2. Поэтому для стран Евразийского союза актуальным становится анализ экономического эффекта от замены двигателей класса IE1 на двигатели класса IЕ2. В данной работе представлен сравнительный анализ показателей энергопотребления асинхронных электродвигателей классов энергоэффективности IЕ1 и IЕ2 в электроприводе центробежного насоса мощностью 11 кВт системы водоснабжения с дроссельным регулированием. Асинхронные двигатели питаются напрямую от электрической сети. Обе насосные системы имеют один и тот жее график расхода жидкости, характерный для разомкнутых насосных систем. Количество расходуемой насосом воды регулируется за счет дросселирования. Получены результаты по суточному и годовому энергопотреблению двух рассмотренных конфигураций насосной системы. Показано что система, где применяется асинхронный двигатель класса энергоэффективности IЕ2, обеспечивает экономию 118,6 евро за год и 2000 евро за жсизненный цикл, по сравнению с асинхронным двигателем класса IЕ1. Рассчитан срок окупаемости двигателя класса IЕ2, который

(c) S.Kh. Oshurbekov, V.M. Kazakbaev, V.A. Prakht, V.A. Dmitrievskii, A.S. Paramonov 
составляет 5 месяцев в случае введения в строй новой установки и 2 года, в случае замены двигателя в работающей установке. Библ. 25, табл. 5, рис. 4.

Ключевые слова: асинхронный двигатель, дроссельное регулирование, срок окупаемости, центробежный насос, энергоэффективность, энергопотребление.

Introduction. The high energy intensity of modern industry determines the high urgency of increasing the energy efficiency of production. Electric motors consume about $70 \%$ of the electricity in industrial applications. Therefore, in many countries around the world, a ban is gradually being introduced on the use of motors with low energy efficiency classes. However, in Russia today, mainly electric motors of low energy efficiency class IE1, in accordance with the IEC 60034-30 Standard, are used. Motors of IE2 class of domestic production are also presented on the Russian market [1]. However, the demand for energy efficient motors in Russia is small due to the low cost of electricity compared to the countries of the European Union. For comparison, the price of electricity for industrial consumers in Germany is about $0.2 \mathrm{EUR} / \mathrm{kW} \cdot \mathrm{h}$, while in Russia it is only about $0.057 \mathrm{EUR} / \mathrm{kW} \cdot \mathrm{h}[2,3]$.

In the European Union, since 2017, in general industrial applications, it is permissible to use motors of classes not lower than IE3, for power of $0.75-375 \mathrm{~kW}$. Moreover, since the 1st of July, 2023 in the European Union, motors with power of more than $75 \mathrm{~kW}$ must comply with the IE4 class [4]. In the future, there are plans to expand the mandatory class IE4 for lower power motors and move to the mandatory class IE5 for powerful motors [5]. It should be noted that even in modern conditions, the use of IE4 and IE5 class motors can be justified due to high, constantly increasing prices for energy carriers and the need to reduce the impact on the environment [6].

The massive use of motors of higher energy efficiency classes will significantly reduce energy consumption, reduce the energy intensity of the gross domestic product, and will also contribute to improving the environmental situation by reducing the emission of harmful substances during electricity generation. The use of energy-efficient motors is consistent with the achievement of the goals stated in the energy and environmental strategies of various countries: the European Union (European Green Deal [6]), the USA (State Energy Program), Switzerland (supports the Paris Agreement), China (supports the Paris Agreement), Japan (Net Zero Energy Building), South Korea (supports the Paris Agreement), as well as the Russian Federation [7], etc.

Therefore, according to the decision of the Commission of the Eurasian Economic Union on the requirements for the energy efficiency of energyconsuming devices [8], since the $1^{\text {st }}$ of September, 2021 the efficiency value for motors with power of $0.75-375 \mathrm{~kW}$ should not be less than the values established for the IE2 energy efficiency class. And from the $1^{\text {st }}$ of September, 2023 the efficiency of motors with power of 7.5-375 $\mathrm{kW}$ should already correspond to the IE3 class. The IE3 class requirement since the $1^{\text {st }}$ September 1, 2025 will also be extended to 0.75-7.5 kW motors [8].

The obligatory transition to IE2 class motors in Russia and the countries of the Eurasian Economic Union makes it possible to hope that in the future, albeit with a certain time delay due to objective economic reasons, the requirements for the energy efficiency of motors will approach the modern requirements of the European Union.

Pump systems consume about $22 \%$ of the world's electricity [9]. A large number of works [10-16] are devoted to the issues of comparing the energy consumption of pump systems using different motors with different IE classes. However, all of these papers deal with pump systems with motor speed control using a frequency converter. Despite the high efficiency, as well as the best static and dynamic control characteristics of the AC drive with a frequency converter, due to the high cost of the converter, most of the pump drives are still powered directly from the mains [9]. For example, the share of variable speed drives in the German market is about $30 \%$, and in the Swiss market - $20 \%$ [17]. In Russia and other CIS countries, the share of variable frequency drives is traditionally lower than in the European Union.

For pumps powered directly from the mains, the comparison of energy consumption when using motors with different IE classes is considered much less often. Or example, in [9] a comparative analysis of the energy consumption of synchronous and induction motors of IE3 and IE4 classes with direct power supply from the network in the electric drive of a centrifugal pump with throttle control is considered. It is also shown in [9] that when choosing a motor, it is necessary to take into account not only the energy efficiency class, but also the load cycle in which the motor operates, and, accordingly, the efficiency of the motor at reduced loads. However, the use of motors of classes IE3 and IE4 is currently not legally supported in all countries.

Based on the above literature review, it can be concluded that the issues of comparing motors of different energy efficiency classes in pump units with an uncontrolled speed remain insufficient highlighted. 
The goal of this work is a comparative analysis of the energy consumption of $11 \mathrm{~kW}$ direct-on-line induction motors with energy efficiency classes IE1 and IE2 in an electric drive of a throttle-controlled centrifugal pump.

The urgency of this work is due to the need to assess the economic effect of replacing IE1 class motors with IE2 class motors for such a common class of mechanisms as centrifugal pumps, in view of the imminent introduction of the mandatory use of IE2 class motors in the countries of the Eurasian Union. For comparison, the energy consumption indicators and the costs of motors of the IE1 and IE2 classes over the life cycle are compared, the payback period of the IE2 class motor is analyzed. In [18], such an analysis was carried out for the particular case of a $15 \mathrm{~kW}$ pump unit. This work expands on this analysis.

Pump characteristics. For the calculation, a Calpeda NM 50/20A/ B pump with power of $11 \mathrm{~kW}$ was selected [19]. The rated speed of the pump is $2900 \mathrm{rpm}$.

The maximum performance of the pump system corresponds to the point at which the water flow rate is $10 \%$ higher than at the point with the best efficiency point (BEP) $Q_{110 \%}=1.1 \cdot Q_{b e p}=66 \mathrm{~m}^{3} / \mathrm{h}$.

Figure 1, $a$ shows the catalog $Q-H$ characteristic of the pump [19], and Fig. 1,b presents the dependence of the mechanical power of the pump drive motor depending on the water supply at the rated speed [19].
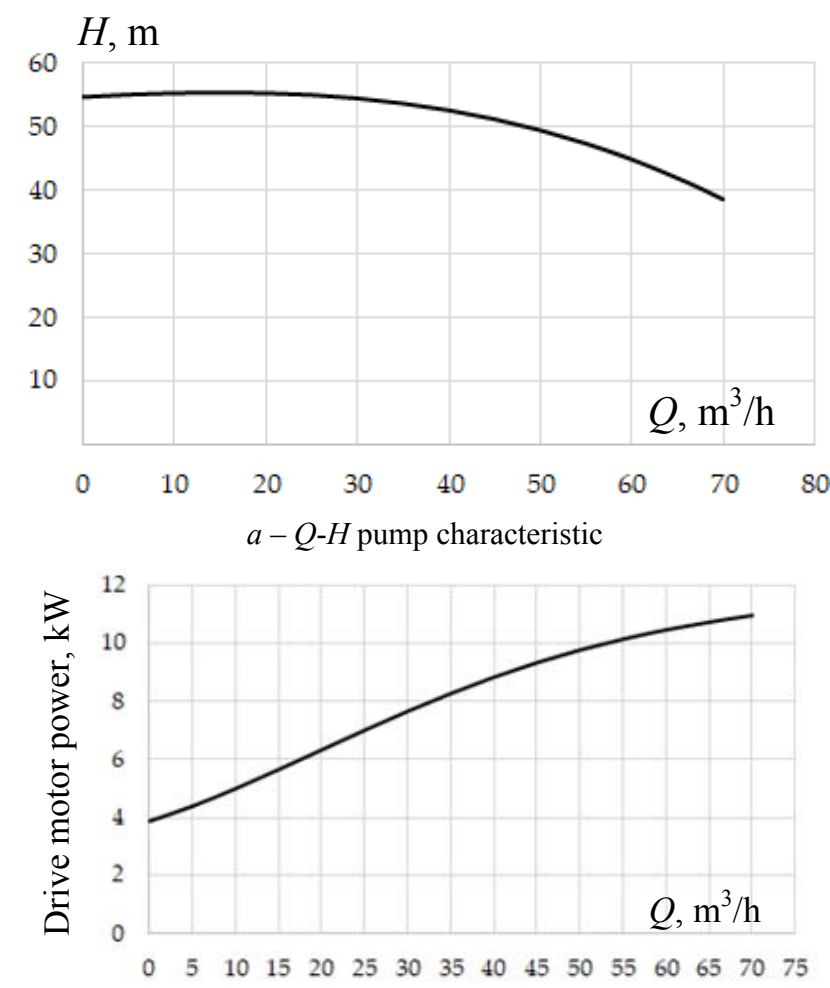

$b$ - required mechanical power of the motor depending on the flow rate

Fig. 1
Characteristics of induction motors. For the calculation the asynchronous motors of Russian production: 7AVEC160M2ie1 (class IE1) and 7AVEC160M2ie2 (class IE2) of the 7AVE series [1] with power of $11 \mathrm{~kW}$ were selected. The efficiency values of these motors in the nominal mode are equal to $88.2 \%$ and $90 \%$, respectively.

Table 1 shows data on the efficiency of the selected motors in 5 different load modes. $P_{\text {mech }}$ is the mechanical power of the motor; $P_{n}$ is the rated mechanical power of the motor. These data are also shown in Fig. 2.

Table 1

\begin{tabular}{|c|c|c|c|c|c|}
\multicolumn{7}{|c|}{ Motor efficiency data } \\
\hline \multirow{2}{*}{ Motor } & \multicolumn{5}{|c|}{ Motor efficiency, \% } \\
\cline { 2 - 6 } & $\begin{array}{c}P_{\text {mech }}= \\
=0.25 \cdot P_{n}\end{array}$ & $\begin{array}{c}P_{\text {mech }}= \\
=0.5 \cdot P_{n}\end{array}$ & $\begin{array}{c}P_{\text {mech }}= \\
=0.75 \cdot P_{n}\end{array}$ & $\begin{array}{c}P_{\text {mech }}= \\
=P_{n}\end{array}$ & $\begin{array}{c}P_{\text {mech }}= \\
=1.25 \cdot P_{n}\end{array}$ \\
\hline IM IE1 & 79.5 & 86.6 & 88.4 & 88.2 & 85.8 \\
\hline IM IE2 & 83.8 & 89.2 & 90.4 & 90 & 88.5 \\
\hline
\end{tabular}

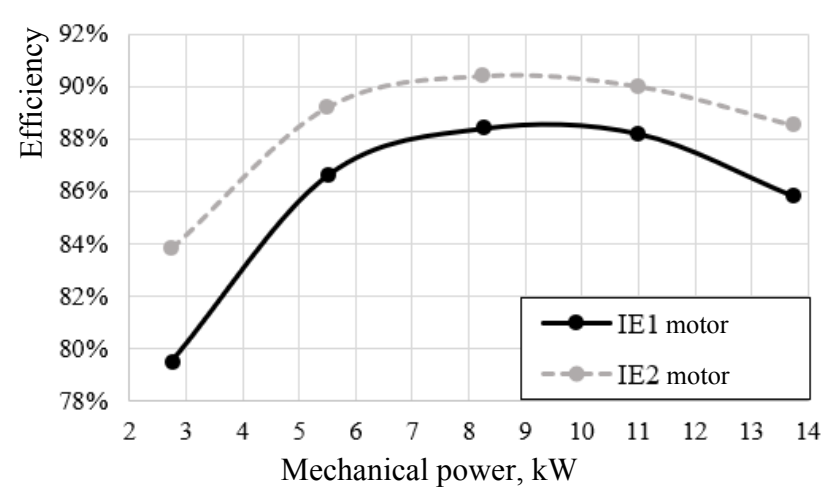

Fig. 2. Efficiency curves of motors

Pump working points. An open-loop pumping system is considered, the water flow rate of which varies in the range from $75 \%$ to $110 \%$ of the flow rate $Q_{b e p}$, which corresponds to the working point of the pump with the highest efficiency (the best efficiency point, BEP). $25 \%$ of the time the pump operates at a point with a flow rate of $0.75 \cdot Q_{b e p}, 50 \%$ of the time - with a flow rate $Q_{b e p}$, and another $25 \%$ of the time - with a flow rate of $1.1 \cdot Q_{\text {bep }}$. This dependence is diagrammatically shown in Fig. 3. This load curve is recommended by the Europump manufacturer association for estimating the energy consumption of pumps with fixed drive [20].

At the maximum water flow rate $\left(Q=1.1 \cdot Q_{b e p}\right)$, the valve is fully opened, and to ensure flow rates equal to $Q_{b e p}$ and $0.75 \cdot Q_{b e p}$, the valve is partially closed so that the system characteristic changes, and the point of its intersection with the pump characteristic moves to the left. Figure 4 shows the $Q-H$ characteristic of the pump and the characteristics of the hydraulic system at various working points. 


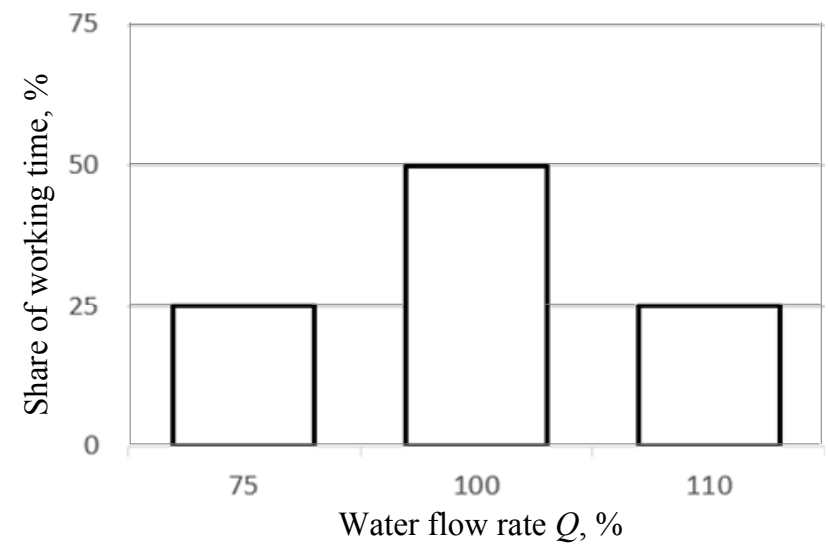

Fig. 3. Water flow rate diagram per cycle [20]

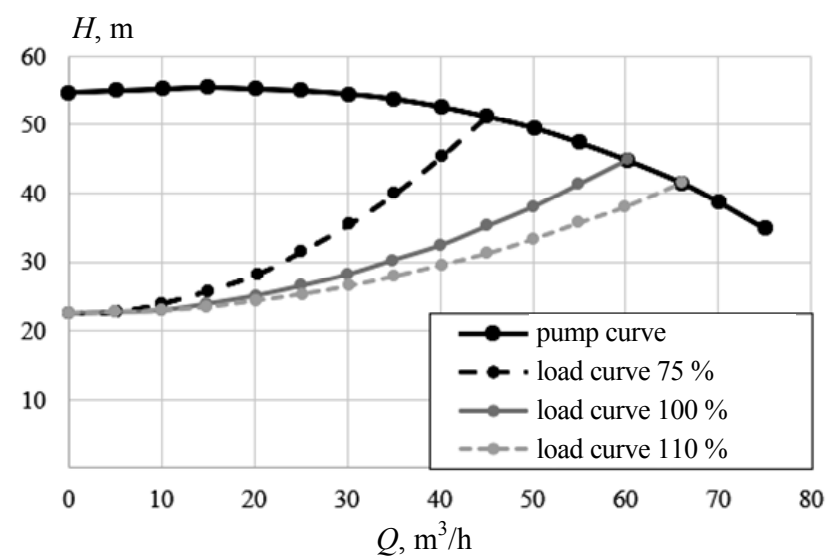

Fig. 4. $Q-H$ characteristic of the pump and curves of the system

To assess energy consumption, the mechanical power of the drive motor is first calculated, in three modes shown in Fig. 3. When regulating the water flow by throttling, the working points of the pump system move along $\mathrm{Q}-H$ pump characteristic by measuring the characteristic of the hydraulic system. The characteristic of the hydraulic system is described by the following equation [9]:

$$
H=H_{s t}+k \cdot Q^{2},
$$

where $Q$ and $H$ are the required values of water supply and pressure of the hydraulic system (hydraulic load); $H_{s t}$ is the static pressure of the hydraulic system $\left(H_{s t}=H_{b e p} / 2=22.5 \mathrm{~m}\right) ; k$ is the coefficient of friction of the hydraulic system, the value of which depends on the value of the valve opening.

Table 2 shows the results of calculating the mechanical power $\left(P_{\text {mech }}\right)$ and other characteristics of the pump at three different water flow rates corresponding to Fig. 3.

The coefficient of friction for different $Q$ is calculated based on (1) as $k=\left(H-H_{s t}\right) / Q^{2}$.
Pump cycle data

\begin{tabular}{|c|c|c|c|c|c|}
\hline$Q, \%$ & $k, \mathrm{~h}^{2} / \mathrm{m}^{5}$ & $Q, \mathrm{~m}^{3} / \mathrm{h}$ & $H, \mathrm{~m}$ & Pump efficiency, $\%$ & $P_{\text {mech }}, \mathrm{kW}$ \\
\hline 75 & 0.014 & 45 & 51.31 & 67.3 & 9.35 \\
\hline 100 & 0.006 & 60 & 45.00 & 70.3 & 10.47 \\
\hline 110 & 0.004 & 66 & 41.47 & 69.2 & 10.78 \\
\hline
\end{tabular}

The pump efficiency is calculated as $P_{h y d r} / P_{\text {mech }}$, where $P_{\text {hydr }}=\rho \cdot g \cdot H \cdot Q$ is the hydraulic power of the pump; $\rho=1000 \mathrm{~kg} / \mathrm{m}^{3}$ is the density of the liquid; $g=9.81 \mathrm{~m} / \mathrm{s}^{2}$ is the acceleration of gravity; $P_{\text {mech }}$ is determined according to the dependence shown in Fig. 1,b.

Power consumption of the pump unit. Efficiency values of motors at different working points (Table 3) are found according to the dependencies shown in Fig. 2.

Table 3

Efficiency of motors at the considered working points of the pump

\begin{tabular}{|c|c|c|c|}
\hline \multirow{2}{*}{$Q, \%$} & \multirow{2}{*}{$P_{\text {mech }}, \mathrm{kW}$} & \multicolumn{2}{|c|}{ Motor efficiency, \% } \\
\cline { 3 - 4 } & 9.35 & IE1 IM & IE2 IM \\
\hline 75 & 10.47 & 88.32 & 90.24 \\
\hline 100 & 10.78 & 88.22 & 90.08 \\
\hline 110 & & & 90.03 \\
\hline
\end{tabular}

Using the data from Table 3, it is possible to find the values of the consumed electrical power at the considered working points, according to the formula:

$$
P_{1}=P_{\text {mech }} / \eta_{\text {motor }}
$$

where $\eta_{\text {motor }}$ is the motor efficiency.

The results of this calculation are shown in Table 4, in which $i=1 . .3$ is the number of the considered load point.

Table 4

Electrical power consumed by the motors at the considered working points of the pump

\begin{tabular}{|c|c|c|c|c|}
\hline \multirow{2}{*}{$i$} & \multirow{2}{*}{$Q, \%$} & \multirow{2}{*}{$t_{i} / t_{\text {sum }}, \%$} & \multicolumn{2}{|c|}{$P_{1}, \mathrm{~kW}$} \\
\cline { 4 - 5 } & & IM class IE1 & IM class IE2 \\
\hline 1 & 75 & 25 & 10.585 & 10.360 \\
\hline 2 & 100 & 50 & 11.865 & 11.623 \\
\hline 3 & 110 & 25 & 12.223 & 11.997 \\
\hline
\end{tabular}

Using the results obtained (see Table 4), we calculate the daily electricity consumed $\left(E_{d a y}\right)$, the annual electricity consumed $\left(E_{\text {year }}\right)$, the sum of the annual energy costs $\left(C_{\text {year }}\right)$ and the annual savings $\left(S_{\text {year }}\right)$ for a pump system with an IE2 motor, compared to pump system with an IE1 class motor [9]: 


$$
\begin{gathered}
E_{\text {day }}=\frac{t_{\text {sum }}}{1000} \cdot \sum_{i=1}^{3}\left(P_{1 i} \cdot \frac{t_{i}}{t_{\text {sum }}}\right) \\
E_{\text {year }}=E_{\text {day }} \cdot 365 \\
C_{\text {year }}=E_{\text {year }} \cdot G T \\
S_{\text {year }}=C_{\text {year } 1}-C_{\text {year } 2}
\end{gathered}
$$

where $t_{i} / t_{\text {sum }}$ is the share of the working time of the $i$-th operating mode; $t_{\text {sum }}$ is the working cycle duration $(24 \mathrm{~h})$; $G T=0.057 \mathrm{EUR} / \mathrm{kW} \cdot \mathrm{h}$ is the electricity tariff in Russia for $1 \mathrm{~kW} \cdot \mathrm{h}$ for industry (Moscow, 2019) [2]; $C_{\text {year } 1}$ and $C_{\text {year } 2}$ are the sum of annual energy costs of the first (when using an IE1 class motor) and second (IE2 class motor) pump systems configuration.

We also estimate the energy consumption over the entire life cycle of the pump system, which is usually 20 years [21]. Estimation of the cost of energy during the entire life cycle of the pump system is determined by the following formula [21]:

$$
C_{l c c}=\sum_{m=1}^{n}\left(\frac{C_{\text {year } m}}{\left(1+[y-p]^{m}\right)}\right),
$$

where $C_{\text {year } m}$ is the sum of electricity costs of the $m$-th year; $y$ is the interest rate of the Central Bank $(y=0.06)$; $p$ is the expected annual inflation $(p=0.04) ; n$ is the service life of the system $(n=20$ years $)$.

The calculation results by (3) - (7) are shown in Table 5.

Table 5

Comparison of energy consumption parameters

\begin{tabular}{|c|c|c|c|c|c|}
\hline Parameters & $\begin{array}{c}E_{\text {day, }} \\
\mathrm{kW} \cdot \mathrm{h}\end{array}$ & $\begin{array}{c}E_{\text {year }}, \\
\mathrm{kW} \cdot \mathrm{h}\end{array}$ & $\begin{array}{c}C_{\text {year }}, \\
\mathrm{EUR}\end{array}$ & $\begin{array}{c}S_{\text {year }}, \\
\mathrm{EUR} / \mathrm{h}\end{array}$ & $\begin{array}{c}C_{\text {lcc }}, \text { thousand } \\
\mathrm{EUR}\end{array}$ \\
\hline IE1 IM & 279.2 & 101921 & 5809 & - & 95.0 \\
\hline IE2 IM & 273.5 & 99827 & 5690 & 118.6 & 93.0 \\
\hline
\end{tabular}

As it can be seen from the Table 5, annual savings $S_{\text {year }}$ are EUR 118.6 with the IE2 motor compared to the IE1 motor. The savings over 20 years (difference in $C_{l c c}$ of the two engines) are 2,000 EUR taking into account interest rates and inflation.

Also, based on the data obtained, we calculate the payback period when using an IE2 class motor. According to [22], the difference in the cost of active materials for an induction motor 7AVE with power of $13 \mathrm{~kW}$ and class IE1 and IE2 is only $6.7 \%$ (in [22] there is no data on active materials for a motor with power $11 \mathrm{~kW})$. However, the difference in the market price of induction electric motors of neighboring energy efficiency classes of the 7AVE series [1], according to [23], is 20-25\%. We calculate the payback period for two cases:

1) when a new pump unit is put into operation with the use of IE2 IM instead of IE1 IM;

2) when replacing the IE1 class IM with the IE2 class IM in a pump unit in operation.
In the first case, the payback period is defined as the ratio of the difference in the cost of IE1 and IE2 class motors to the annual energy savings [24] (8):

$$
T=\left(C_{m 2}-C_{m 1}\right) / S_{\text {year }},
$$

where $T$ is the value of the payback period of the system, year; $C_{m 1}=194.21$ EUR is the cost of an induction motor of class IE1 [25]; $C_{m 2}=1.25 \cdot C_{m 1}=242.76$ EUR is the cost of an induction motor of class IE2 [23].

In the second case, we calculate the payback period as (9):

$$
T=C_{m 2} / S_{\text {year }}
$$

The payback periods, calculated according to (8), (9), are 0.41 years (approximately 5 months) when a new pump unit with IM IE2 is put into operation and 2.03 years when the IM of the IE1 class is replaced by the IM of the IE2 class in the existing unit.

\section{Conclusions.}

This paper compares the energy efficiency indicators of a pump unit with power of $11 \mathrm{~kW}$ when using induction motors of IE1 and IE2 classes. In both cases, the same flow rate graph is considered, typical for openloop pump systems. The flow rate is regulated by throttling the pipeline.

It is shown that a system using an IE2 class induction motor saves EUR 118.6 per year and EUR 2,000 (including the interest rate and inflation) per life cycle, compared to a system using an IE1 class induction motor.

The payback period when using a more expensive IE2 class motor instead of an IE1 class motor is 5 months when a new pump unit is put into operation and 2.03 years when replacing motors in a pump unit in operation.

The short payback period for the first case allows to conclude that the use of IE2 motors in new installations is very profitable at current prices for motors and electricity.

\section{Acknowledgment.}

The work was partially supported by the Ministry of Science and Higher Education of the Russian Federation (through the basic part of the government mandate, Project No. FEUZ-2020-0060).

\section{REFERENCES}

1. Technical catalog. Series of low-voltage asynchronous motors 7AVE, dimensions 160-315mm, energy efficiency classes $I E 1$, IE2, IE3. Available at: http://www.xn--h1aambls2f.xn-p1ai/produkcziya/elektrodvigateli/nizkovoltnye-asinhronnyedvigateli-7ave/ (accessed 01 May 2020). (Rus).

2. Electricity tariffs for medium-sized enterprises in 2020. Available at: https://time2save.ru/articles/tarify-naelektroenergiyu-dlya-srednih-predpriyatiy-v-2018 (accessed on 11 July 2020). (Rus). 
3. Eurostat Data for the Industrial Consumers in Germany. Available

at:

https://appsso.eurostat.ec.europa.eu/nui/show.do?dataset=nrg pc 205\&lang=en.

4. Commission Regulation (EU) 2019/1781 of 1 October 2019 laying down ecodesign requirements for electric motors and variable speed drives pursuant to Directive 2009/125/EC of the European Parliament and of the Council, amending Regulation (EC) No 641/2009 with regard to ecodesign requirements for glandless standalone circulators and glandless circulators integrated in products and repealing Commission Regulation (EC) No 640/2009, Document 32019R1781. Available at: https://eurlex.europa.eu/eli/reg/2019/1781/oj.

5. Doppelbauer M. Update on IEC motor and converter standards. 6th International Motor Summit for Energy Efficiency powered by Impact Energy, Motor Summit, 2016.

6. Annex to the Communication from the Commission to the European Parliament, the European Council, the Council, the European Economic and Social Committee and the Committee of the Regions. The European Green Deal. Brussels, 11.12.2019, COM (2019) 640 final. Available at: https://ec.europa.eu/info/sites/info/files/european-green-dealcommunication-annex-roadmap_en.pdf.

7. Long-term development strategy of the Russian Federation with low greenhouse gas emissions until 2050. Available at: https:/economy.gov.ru/material/file/babacbb75d32d90e28d329

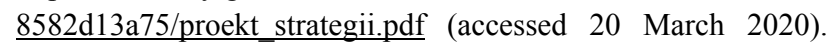
(Rus).

8. Decision of the Council of the Eurasian Economic Commission of August 8, 2019 no. 114 «On the technical regulation of the Eurasian Economic Union «On requirements for the energy efficiency of energy-consuming devices». Available

https://www.garant.ru/products/ipo/prime/doc/73240518

(accessed 11 May 2020). (Rus).

9. Goman V.V., Oshurbekov S.Kh., Kazakbaev V.M., Prakht V.A., Dmitrievskii V.A. Comparison of energy consumption of various electrical motors operating in a pumping unit. Electrical engineering \& electromechanics, 2020, no. 1, pp. 16-24. doi: 10.20998/2074-272X.2020.1.03.

10. Ahonen T., Orozco S.M., Ahola J., Tolvanen J. Effect of electric motor efficiency and sizing on the energy efficiency in pumping systems. 2016 18th European Conference on Power Electronics and Applications (EPE'16 ECCE Europe), Sep. 2016, Karlsruhe, pp. 1-9. doi: 10.1109/EPE.2016.7695671.

11. Van Rhyn P., Pretorius J.H.C. Utilising high and premium efficiency three phase motors with VFDs in a public water supply system. 2015 IEEE 5th International Conference on Power Engineering, Energy and Electrical Drives (POWERENG), May 2015, Riga, pp. 497-502. doi: 10.1109/PowerEng.2015.7266367.

12. Brinner T.R., McCoy R.H., Kopecky T. Induction versus permanent-magnet motors for electric submersible pump field and laboratory comparisons. IEEE Transactions on Industry Applications, 2014, vol. 50, no. 1, pp. 174-181. doi: 10.1109/TIA.2013.2288203.

13. Safin N., Kazakbaev V., Prakht V., Dmitrievskii V., Sarapulov S. Interpolation and analysis of the efficiency of a synchronous reluctance electric drive at various load points of a fan profile. 2018 25th International Workshop on Electric Drives: Optimization in Control of Electric Drives (IWED), Moscow, 2018, pp. 1-5. doi: 10.1109/IWED.2018.8321372.

14. Kazakbaev V., Prakht V., Dmitrievskii V., Ibrahim M., Oshurbekov S., Sarapulov S. Efficiency Analysis of Low Electric Power Drives Employing Induction and Synchronous Reluctance Motors in Pump Applications. Energies, 2019, vol. 12, no. 6, p. 1144. doi: 10.3390/en12061144.

15. Kazakbaev V.M., Prakht V.A., Dmitrievskii V.A. A comparative performance analysis of induction and synchronous reluctant motors in an adjustable-speed electric drive. Russian Electrical Engineering, 2017, vol. 88, no. 4, pp. 233-238. doi: 10.3103/s106837121704009.

16. Kazakbaev V., Prakht V., Dmitrievskii V., Sarapulov S., Askerov D. Comparison of power consumption of synchronous reluctance and induction motor drives in a $0.75 \mathrm{~kW}$ pump unit. 2017 International Siberian Conference on Control and Communications (SIBCON), Jun. 2017, Astana, pp. 1-6. doi: 10.1109/SIBCON.2017.7998485.

17. Phillips R., Tieben R. Improvement of Electric Motor Systems in Industry (IEMSI). Proceedings of the 10th international conference on energy efficiency in motor driven systems (EEMODS' 2017), Rome, Italy, September 6-8, 2017. pp. 53-67. doi: 10.2760/345473.

18. Oshurbekov S., Kazakbaev V., Prakht V., Dmitrievskii V. Comparative Study of Energy Consumption of $15 \mathrm{~kW}$ Induction Motors of IE1 and IE2 Efficiency Classes in Pump Applications. Proceedings of 2020 XI International Conference on Electrical Power Drive Systems (ICEPDS), Saint-Petersburg, Russia, 2020, October 04-07, pp. 1-6. (Accepted for publication).

19. NM, NMS, Close Coupled Centrifugal Pumps with Flanged Connections; Catalogue; Calpeda, 2018. Available at: https://www.calpeda.com/system/products/catalogue 50hzs/53 len/NM_NMS_EN2018.pdf?1549893188 (accessed 23 March 2019).

20. Extended product approach for pumps, Copyright (C) 2014 by Europump. Published by Europump.

21. Pump Life Cycle Costs: A Guide to LCC Analysis for Pumping Systems. Executive Summary. Hydraulic Institute (Parsippany, NJ); Europump (Brussels, Belgium); Office of Industrial Technologies Energy Efficiency and Renewable Energy U.S. Department of Energy (Washington, DC). January 2001, pp. 1-19. Available at: https://www.energy.gov/sites/prod/files/2014/05/f16/pumplcc_1 001.pdf.

22. Bespalov V.Y., Kobelev A.S., Kruglikov O.V., Makarov L.N. Constructing and mastering the production of energyefficient asynchronous motors of mass-market series. Russian Electrical Engineering, 2015, vol. 86, no. 4, pp. 194-200. doi: 10.3103/S1068371215040033.

23. Kobelev A.S. Cast copper rotor motors: between the price and the performance. Constructor. Mechanical engineer Journal, 2020. Available at: https://konstruktor.net/podrobneeelekt/dvigateli-s-litym-mednym-rotorom-shpagat-mezhducenoj-i-ehffektivnostju-2464.html (Accessed 11 May 2020). (Rus). 
24. Tyuteva P.V. Algorithm for evaluating the energy efficiency of asynchronous motors in pumping units. Bulletin of the Tomsk Polytechnic University, 2009, vol. 315, no. 4, pp. 75-79. (Rus).

25. Price list, induction motors of the AIR series, class IE1. Available at: http://www.a-a-a.ru/01-pr.html (Accessed 22 June 2020). (Rus).

Received 12.07.2020
S.Kh. Oshurbekov,

V.M. Kazakbaev ${ }^{1}$, Candidate of Technical Science,

V.A. Prakht ${ }^{1}$, Candidate of Technical Science,

V.A. Dmitrievskii ${ }^{1}$, Candidate of Technical Science,

A.S. Paramonov ${ }^{1}$,

${ }^{1}$ Ural Federal University,

19, Mira Str., Ekaterinburg, 620002, Russia, e-mail: safarbek.oshurbekov@urfu.ru,

vadim.kazakbaev@urfu.ru,

va.prakht@urfu.ru,

vladimir.dmitrievsky@urfu.ru,

paramonov.aleksey@inbox.ru

How to cite this article:

Oshurbekov S.Kh., Kazakbaev V.M., Prakht V.A., Dmitrievskii V.A., Paramonov A.S. Analysis of electricity consumption of induction motors of IE1 and IE2 efficiency classes in a $11 \mathrm{~kW}$ pump installation. Electrical engineering \& electromechanics, 2020, no. 5, pp. 18-24. doi: 10.20998/2074-272X.2020.5.03. 